\title{
The Role of Plea Agreement in Resolution of a Criminal Case in the Criminal Proceedings of the Republic of Kosovo
}

\author{
Albulena Hajdari \\ Professor at College UBT, Prishtina, Kosovo \\ Email:albulenahajdari@gmail.com Tel:+37744.64.015.
}

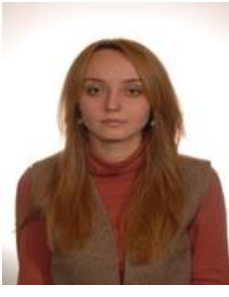

W) Check for updates

\begin{abstract}
Plea agreement is an important criminal-procedural institute through which is granted the possibility to the defendant to plead guilty, and in return to acquire facilities concerning criminal sanctions as well as other considerations in the interest of justice including the possibility of acquittal of the defendant from the punishment. This institute may be initiated by the defendant, his defense counsel and the state prosecutor which are also its negotiating subjects. In order for this criminal-procedural institute to affect in resolution of a criminal case must be approved by the competent court. Plea agreement may be initiated for all types of criminal offenses irrespective of their importance. As it derives by the modest results of this scientific paper criminal case resolution through plea agreement in Kosovo continues to be applicable relatively rarely which is not in line with current trends existing nowadays in modern countries. During preparation of this scientific paper I have used legal, comparative and statistical methods, as well as it has been consulted a relatively rich scientific literature.
\end{abstract}

Keywords: Agreement, Punishment, State prosecutor, Defendant, Court.

\section{Introduction}

Plea agreement as a criminal-procedural institute which facilitates criminal case resolution in general terms has a long and substantial historic of its application to criminal proceedings. This fact nonetheless is not present in Kosovo reality (plea agreement for the first was foreseen in 2008 and is applicable in only 3.23\% of cases). This institute is initiated and negotiated between the state prosecutor and the defendant as well as his defense counsel, whereas is approved by the competent court. This institute has its constituent elements and his characteristics and normally (after being approved by the competent court) is mandatory for the parties. Plea agreement represents an important institute for criminal-procedural parties and social interest. Through application of this institute budget expenditures shall be shortened as well as the time of criminal case resolution, there shall be increased the level of communication and benefits between criminal-procedural parties, are achieved important considerations in the interest of justice etc. The fact itself that this institute is rarely applicable when it comes to criminal case resolution in Kosovo raises the need for it to be promoted more by competent authorities (for example by Kosovo Judicial Council) and civil society as well and to be developed training programs that enables and motivates criminal procedure authorities in order to use this institute more often.

\section{Meaning of Plea Agreement}

Plea agreement as a criminal-procedural institute for the first time was foreseen with the amendments and supplements of the Provisional Criminal Procedure Code of Kosovo in 2008. ${ }^{1}$ This institute afterwards has become an integral part of the Criminal Procedure Code of the Republic of Kosovo in 2012.2 Consequently, according to Kosovo legal doctrine and legal meaning the plea agreement represents an important criminal-procedural institute through which is made possible to the defendant to plead guilty and in return to acquire certain facilities concerning punishments, respectively criminal sanctions (Hajdari, 2013). Plea agreement is an agreement between parties based on which the state prosecutor is obliged to mitigate the indictment by making a more lenient legal qualifications of the criminal offence or by removing some of its points and proposing to the court an imposition of a more lenient punishment, whereas the defendant is obliged to plead guilty for the criminal offence he/she is charged with by avoiding the main trial before the jury. ${ }^{3}$

${ }^{1}$ See Article 6 of Law No. 03 / L-003 On Amending and Supplementing the Provisional Criminal Procedure Code of Kosovo No.2003 / 26. Within these amendments and supplements, the Plea Agreement occupies the central place.

${ }^{2}$ See Article 233 of the Code No. 04 / L-123 of the Criminal Procedure.

${ }^{s}$ The renounce of defendant from the main trial before the jury makes it possible to resolve the criminal case faster and more efficiently. 
Plea agreement first of all is American criminal procedure institute through which American courts resolve most of the criminal cases (Bojović, 2009). ${ }^{5}$ It is considered that in American criminal procedure over $90 \%$ of criminal cases are resolved through application of the plea agreement (Thaman 2002; Nikolić, 2009). On the contrary, in Kosovo this institute is marking a relatively rare implementation, which is about $3.23 \%$.

In the United States, in some other countries but also in Kosovo this institute may be applicable to all types of criminal offences. "It is not limited to the gravity of criminal offence which means that it can be applicable as in case of minor criminal offences as well as in cases of serious criminal offences. Furthermore, a large number of plea agreements is referred exactly to serious criminal offences. In meanwhile, in most Europe continental legislations plea agreements mostly are applicable for minor criminal offenses and for moderately serious criminal offenses 1 (Damaška, 2004).

\section{Elements and Characteristics of Plea Agreement}

As any other criminal-procedural institute also the plea agreement consists of its basic elements, as well manifests several characteristics that together determine its identity. If we refer to solutions included in Article 233 of the Criminal Procedure Code of the Republic of Kosovo it can be concluded that the basic elements of the plea agreement shall be considered:

1. Parties' compliance concerning conditions on guilty plea. These conditions refer to guilty plea by the defendant and recommendation that should be given to the court for imposition of a more lenient punishment or other considerations in the interest of justice (such as acquittal from punishment).

2. Granting written authorization to the competent court by the Chief Prosecutor of the respective prosecution office to have meetings on guilty plea discussions. Without this authorization negotiations on guilty plea cannot be initiated.

3. The presence of the defendant and his defense counsel at the meetings to be decided by the prosecutor of the case regarding the guilty plea. The presence of these subjects is mandatory.

4. Inclusion in the agreement reached on guilty plea of all terms of the agreement. The agreement should clearly address all issues that the state prosecutor, the defendant and his defense counsel have been accorded.

5. Signing the agreement by the Chief Prosecutor of the respective prosecution office, the defendant and his defense counsel. Without signatures of these subjects, the agreement cannot be processed for approval in court.

6. Admissibility of plea agreement by the competent court. Without such acceptance, the agreement reached between the parties has no legal value, which means that it has no binding force for the court.

However, as plea agreement characteristics may be considered:

1. Time of plea agreement negotiation, paragraph 1 of Article 233 of the Criminal Procedure Code considers as a better possibility to negotiate the plea agreement before the indictment has been filed. However, in accordance with paragraph 2 of this article, considering the advantages of this institute, the legislator has offered the possibility that the negotiation of the plea agreement can be made even after the indictment has been filed, but until the end of the main trial. This means that the issue of guilty plea agreement can be opened even in the closing statements, for which authorized subjects should be given the right time to start the discussions and reach agreement on the guilty plea agreement.

2. Initiating and negotiating parties to reach a guilty plea agreement. According to the Criminal Procedure Code of the Republic of Kosovo, initiating discussions to discuss the plea agreement can be made by the defendant, his defense counsel and by the state prosecutor. These are also the subjects that negotiate the conditions for reaching the agreement. It is worth mentioning the fact that in the case of the state prosecutor, negotiation can only be done if the Chief Prosecutor of the respective prosecutor's office agrees. ${ }^{6}$

3. Informing the injured party about the agreement reached. Pursuant to paragraph 8 of Article 233 of the Criminal Procedure Code, the state prosecutor shall inform the injured party of the negotiated plea agreement, once the agreement reaches its final form. When the injured party has a claim for damages arising from the criminal conduct that has been filed or is charged in the indictment, the plea agreement must address the injured party's claim, and the state prosecutor must inform the injured party that the defendant is seeking to negotiate a plea agreement. The injured party must be given an opportunity to present a statement to the court regarding such property claim prior to the court's acceptance of the plea agreement (Hajdari, 2013).

4. Court position in relation to plea agreement. According to paragraph 10 of Article 233 of the Code of Criminal Procedure, the court should not participate in the plea agreement but has been granted the opportunity to set reasonable time, not longer than three months, for the completion of negotiations in order to prevent the prolongation of the procedure. The court is in fact the authority that, depending on the circumstances of the case, may approve or reject the plea agreement (Sahiti et al., 2014).

5. The status of the defendant as a cooperative witness. Within plea agreement can take place also the issue of the defendant's announcement as a cooperative witness. Therefore, when the defendant agrees to be a cooperative witness, upon request of any party the court may order a hearing to review the plea agreement that shall be closed to the public and may order the plea agreement in writing to be closed.

6. The effects of the plea agreement. The plea agreement accepted by the court is binding for the parties. Consequently, after the court has accepted the written plea agreement but before the sentence is imposed, it

${ }^{4}$ Regardless of this fact, even nowadays in USA concerning this institute debates arise even very harsh between its supporters and opponents.

${ }^{5}$ The first case of plea agreement is marked in 2008 (Case Stevens) where the plaintiff charged the defendant with four offenses of illicit trade with alcohol. In this proceedings parties had reached agreement that the defendant to plead guilty for one criminal offence in exchange the plaintiff to withdraw from three other criminal offences by means of which the judge was obliged to impose the foreseen punishment.

${ }_{6}$ All plea agreements should be in writing and accepted by the Chief Prosecutor of the respective prosecution office before being formally provided to the defendant for signature (CPPRK, Article 233 paragraph 4). 
may not allow the defendant or the state prosecutor to withdraw the plea agreement unless the court finds that anyone from the conditions provided in the agreement is not fulfilled.?

\section{Parties to the Plea Agreement}

As abovementioned, in matters relating to plea agreement with concrete roles and responsibilities, result to manifest their presence the state prosecutor, the Chief Prosecutor of the respective prosecutor's office, the defendant, his defense counsel, and the single trial judge or presiding judge. Each of these subjects has a specific role, but all together exert their influence in achieving the agreement or its concretization.

The state prosecutor may be the initiating subject of the agreement and negotiator on its reaching. He may initiate negotiations on plea agreement in any criminal case regardless of the committed criminal offence gravity. This interest the state prosecutor may express to the defendant directly (when he has no defense counsel), or his defense counsel, in which case he appoints the relevant hearing and discloses his plan referring to the plea agreement. Before undertaking such an initiative, but also when the initiative comes from the defendant or his defense counsel he must get the consent for this matter of the Chief Prosecutor of the respective prosecution's office. This initiative as abovementioned may be undertaken before the indictment has been filed but also after the indictment has has been filed up to the conclusion of the main trial. After receiving this consent, his position passes on the role of negotiating conditions on guilty plea. In the negotiations he could agree to recommend to the court a more lenient punishment for the defendant, but not below the minimum foreseen by the law, or other considerations in the interest of justice, such as acquittal from punishment.

The Chief Prosecutor of the Prosecutor's Office (the office where the prosecutor of case exercises prosecutorial authorizations) is the authority to which is granted the responsibility of granting written authorization for setting a meeting between the prosecutor of the case and the defendant as well as his defense counsel in order to discuss the conditions on guilty plea, where to the defendants' statements should be given limited immunity. In fact, the Chief Prosecutor of the relevant prosecution office is also the authority without the signature of which the plea agreement cannot be considered. This signature must be obtained prior to the agreement is sent to the defendant for signature (Sahiti and Murati, 2013).

The defendant may be an initiating subject on plea agreement. Duly, he shall exercise this role when he did not engage any defense counsel in criminal proceedings conducted against him. Here it is about indictments' cases for criminal offences in which the defense is not mandatory. Certainly, when his initiative is accepted by the state prosecutor, the defendant together with his defense counsel acquires the position of a plea agreement negotiator. ${ }^{8}$ In this regard, he may have a key role in reaching the agreement, in this case by pleading guilty and being constructive in relation to existing possibilities of admissibility regarding punishment or other considerations which serve to bring the justice concerning the case which is object of trial.

The defendant's defense counsel is the initiating and negotiating subject of plea agreement as the state prosecutor and the defendant. Without his presence, it is not possible to discuss conditions on plea agreement based on the guilty plea agreement. The defense counsel acts and assists the defendant through giving professional legal advice on the accords for accepting the terms of the agreement.

The court is not an initiator nor the negotiator subject on plea agreement. It is the third subject, completely neutral in the process of negotiating the terms of the plea agreement, but not an uninterested subject. ${ }^{9}$ As a matter of fact, despite the fact that the court is neutral in relation to the agreement of parties the legislator has attributed a special role in the context of preventing unnecessary delays in criminal proceedings (Markus, 2006). In fact, the legislator authorizes the competent court to set reasonable deadlines for conclusion of negotiations on reaching the plea agreement. This is a quarterly deadline and it starts to run from the day when the Chief Prosecutor of the relevant prosecution office issues a written authorization to start negotiations on reaching a plea agreement (Hajdari, 2016). Consequently, to the court has been attributed the role of subject who decides about the fate of negotiated and reached agreement between parties. So, the court may approve or reject the written plea agreement. The court may approve or reject the plea agreement, depending on the concrete case and from the assessment of the circumstances concerning the understanding of consequences of guilty plea by the defendant and the assessment of other circumstances as may be : a) Finding whether the guilty plea was made by the defendant's free will, b) The guilty plea is based on the facts and material evidence of the particular case; and c) The lack of circumstances that would determine the dismissal of the indictment (the criminal offence that the accused is charged with does not constitute a criminal offense, there are circumstances that exclude criminal liability, etc.),

Islami et al. (2003). When the court accepts the agreement reached between parties, it decides to put it the same to the case file. In these cases, the court shall, duly, set a date when the parties shall make their statements regarding the criminal sanction, after which the court imposes the punishment for the defendant. ${ }^{10}$ Finally, after the court has approved the written plea agreement, but before the sentence has been imposed, it may allow the parties to renounce the agreement reached. The court shall use this possibility when it finds that any of the terms of the agreement is not fulfilled. "Otherwise, it is a rule that the court should not allow the parties to renounce the reached written plea agreement. ${ }^{11}$

\section{Procedure on Reaching the Plea Agreement}

As abovementioned, the initiation of procedure on reaching the plea agreement has been granted to the parties as a possibility (to the state prosecutor, defendant and his defense counsel). Each of these subjects can use this possibility before the indictment is filed or even after indictment is filed until conclusion of the main trial. The state prosecutor, whether in the role of initiating party or a party which accepted the request for a preliminary meeting

The party seeking to withdraw from the agreement has the burden of proof when submitting that request to the court.

${ }^{8}$ It is so because in discussions about reaching plea agreement the presence of defense counsel is obligatory.

9 This position protects the court in its neutral position towards the parties, and guarantees objectivity and legality in decision-making.

${ }^{10}$ This date may be postponed to cases where to the defendant has been granted the capacity of a cooperative witness so that he can serve the mission of such a witness.

${ }^{11}$ CPKRK, Article 233, paragraph 22. 
by the defendant or his defense counsel to discuss the matter of plea agreement is obliged to inform Chief Prosecutor of the relevant prosecution office which has the authority to give written authorization for a meeting in order to discuss the plea agreement conditions by means of which to the defendant is granted a limited immunity. Certainly, he may not issue authorization on such meeting.

After granting authorization the relevant prosecutor, duly, sets the date of the hearing and summons the defendant and his defense counsel to discuss the conditions for reaching the plea agreement. When parties agree concerning plea agreement conditions, in order for this agreement to be valid it must be signed by the Chief Prosecutor of the respective prosecution office. Such agreement must at least include: a) points of the indictment for which the defendant pleads guilty; b) the fact that the defendant agrees to cooperate (if it has been declared a cooperative witness) and the protective measures applied to him; c) the rights that are waived, d) the defendant's liability to compensate the damage to the injured party; e) the provision by which the parties agree on the limits of sentence to be proposed to the court, respectively other facilities in the interest of justice (for example the release of the defendant from the punishment).

Afterwards, the plea agreement must be presented to the court at an open public hearing, except in cases when the defendant has agreed to be a cooperative witness. When the parties to the agreement have concretized all matters then the prosecutor of the case proceeds the agreement reached in writing to the competent court. The court then reviews it and, depending on the circumstances that characterize the case, may accept or reject the agreement. When the court accepts the agreement it orders the same to be placed in the case file. In these cases as abovementioned, the court sets the date when the parties will make their statements regarding the sentence, after which the court imposes the sentence (Hajdari, 2010).

\section{The Importance of Plea Agreement in Resolution of a Criminal Case}

Plea agreement as a criminal-procedural institute manifests various effects of multiple importance that reflect the extent of individual and social character, and which are of interest to procedural and substantive criminal law, as well as to criminal policy (Latifi et al., 2012); (Milutinović, 1984). As a matter of fact, the plea agreement importance has to do with the fact that application of this institute:

1. Impacts on increasing the efficiency of the prosecuting authorities in resolution of criminal cases. This is due to the fact that during the application of this institute the procedural actions that are standard in criminal proceedings do not apply, which means that the criminal procedure does not pass through the complex and lengthy process of the administration of evidence that is characteristic of the main trial, which is directly affected in shortening the timing of the criminal case conclusion. This approach in conditions when 440832 are pending cases waiting for resolution in the courts of Kosovo, of which about $40 \%$ of them are criminal cases, is of a great criminal-policy importance. ${ }^{12}$

2. Reduces the expenditures of public money that would be spent in conditions of the conducting regular (standard) criminal proceedings for witnesses, experts, lump sum expenses and other expenses, which is considered of a special importance due to the fact that Kosovo continues to have a very limited state budget. ${ }^{13}$

3. It protects the society from the repetition of criminal offenses commission, based on the fact that persons indicted for commission of criminal offenses in relation to which criminal proceedings have been conducted through reaching a guilty plea agreement rarely decide to commit again criminal offenses, in comparison to persons against whom regular criminal proceedings have been applied, despite the verdict rendered by the courts (Hajdari, 2010).

4. The perpetrators of criminal offences shall benefit concerning imposed criminal sanction. When reaching the plea agreement, to them is imposed a more lenient punishment, but they also benefit other facilities in the interest of justice, including the possibility of releasing from the punishment. Thus, to them is made possible that for a shorter period of time to return to their family life and other useful activities (such as schooling, work, etc.).

5. The perpetrator of a criminal offences shall be motivated to be educated with the feeling of repent for the committed criminal offence, apology and compensation of damage for victims of crime. This shall be dictated by the fact that the conclusion of criminal proceedings through reaching the plea agreement may be applicable in practice only if the accused person pleads guilty and repents for its commission, as well as compensates the inflicted damage to the victim. Such an acting approach has been indicated to be very efficient in elimination of the revenge feeling, which concerning several criminal offences as for example regarding criminal offences against life and body, those against sexual integrity etc. continues to be present to a considerable category of victims of these crimes (Hajdari, 2016).

6. Victims of crimes shall be motivated in coordination to criminal procedural bodies to increase the level of communication with perpetrators of criminal offences in their goal to realize easily the compensation of inflicted damage from the criminal offence. In case of criminal proceedings application through the plea agreement it comes faster and easier to a realization of legal-property claims for victims of crimes (Hajdari, 2016).

\section{Several Data on Resolution of Criminal Cases through Plea Agreement in the Republic of Kosovo During the Period of Time 2011-2016}

In order to achieve sustainable conclusions and to address concrete and useful recommendations to relevant state institutions (mainly prosecutions and courts), and society in general by modest results of this scientific paper is considered necessary to research and study Kosovo courts work which the resolution of criminal cases have addressed through plea agreement application institute for the period of time of three years (2014-2016).

\footnotetext{
${ }_{12}$ Court Statistical Report, Annual 2015, Kosovo Judicial Council, Pristina, 2016. See link: http://www.gjyqesori-rks.org/sq/kjc/report/list/1.

${ }^{13}$ This budget in recent years, although increasing, does not exceed more than a billion and a half dollars a year.
} 
We have been focused on this short three-year period of time based on the fact that in comparison to earlier periods the plea agreement institute has manifested a relatively advanced extent of its application. The presentation of the courts work concerning application of this criminal-procedural institute was not an easy matter at all. This due to the fact that in context of criminal case resolution through application of the plea agreement institute for researching period there are no published data. Such data were not published and reflected within reports reflecting the Kosovo Judicial Council activity. Regardless of this fact, in the following handlings, the presentation of cases through application of this institute shall be done based on provided data by the criminal records of three of the seven basic courts currently operating in the territory of Kosovo, and that of the Basic Court of Prishtina, Gjilan and Mitrovica. ${ }^{14}$

In the following, in a special table shall be presented data concerning the number of criminal cases which have been resolved by the Basic Courts of Pristina, Gjilan and Mitrovica through application of the plea agreement institute and criminal cases resolved in general during the period of time $2014-2016$.

Table-1. Data on the number of cases resolved through plea agreement and those resolved in regular court proceedings.

\begin{tabular}{l|l|l|l|}
\hline Years & $\begin{array}{l}\text { Number of cases resolved through plea } \\
\text { agrement }\end{array}$ & $\begin{array}{l}\text { Number of criminal cases resolved in court } \\
\text { proceedings }\end{array}$ \\
\hline $2014-2016$ & 557 & 18012 \\
\hline
\end{tabular}

Source: Criminal records of the Basic Court of Prishtina, Gjilan, Mitrovica and Peja for the period of time $2014-2016$.

According to these data during the period of time 2014 - 2016, the Basic Courts of Prishtina, Gjilan and Mitrovica have resolved 557 criminal cases through application of plea agreement. As it results, the number of cases resolved through application of this institute (557) is very small (3.23\%) in comparison to the number of cases that have been resolved in regular court proceedings (18012). Causes of this situation are linked with the lack of tradition, lack of professional knowledge concerning this institute and lack of readiness concerning its application. Therefore, I consider that in the future Kosovo basic courts should apply more often the resolution of criminal offences through plea agreement institute (in all cases when it comes to fulfillment of legal requirements) always by bearing in mind benefits of the state and the parties when it comes to its application. Therefore, it is recommended for Kosovo courts to avoid in maximum traditional procedures of criminal cases resolution, always when there is a fulfillment of legal requirements and when the application of this institute is assessed to be more reasonable to a case. Certainly, in order for this to happen is required to work harder in terms of increasing professional performances of judges, because in this manner the state and criminal-procedural parties more easily manifest their interest in criminal proceedings.

\section{Conclusion}

Modest results of this scientific paper led me to these conclusions:

1. Plea agreement is a criminal-procedural institute through which is made possible to the defendant to plead guilty and in return of this to acquire certain facilities concerning criminal sanctions, respectively punishments.

2. The Criminal Procedure Code of the Republic of Kosovo has enabled the resolution of a criminal case through the plea agreement for all types of criminal offenses regardless of their gravity. This solution is considered to be reasonable and in accordance with the current trends in contemporary states.

3. Plea agreements includes these basic elements: compliance of the parties concerning plea agreements conditions, the issuing of written authorization to the prosecutor of the case by the Chief Prosecutor of the respective prosecution office to have meetings on plea agreement discussions, the mandatory presence of the defendant and his defense counsel in the meetings to be decided by the prosecutor of the case regarding guilty plea agreements, the involvement in agreement reached on the guilty plea all the terms of the agreement, the signing of the agreement by the Chief Prosecutor of the relevant prosecution office, the defendant and his defense counsel and the admissibility of the plea agreement by the competent court.

4. Plea agreements manifest these characteristics: determining the timing of the plea agreement negotiation, addressing the initiating and negotiating subjects of reaching the guilty plea agreement, informing the injured party of the agreement reached, the court position in relation to the plea agreement, the status of the defendant as a cooperative witness, and the effects of the plea agreement.

5. Initiation of procedure on reaching the plea agreement has been granted to the parties as a possibility (to the state prosecutor, to defendant and his defense counsel). Each of these subjects may use this possibility before the indictment is filed, or even after indictment has been filed, up to the conclusion of the main trial. Meanwhile, the approval subject of such an agreement is the competent court.

6. Kosovo courts during the period of time 2014-2016, have applied the criminal case resolution through plea agreement institute relatively in rare cases. This scientific paper indicates that the Basic Courts of Pristina, Gjilan and Mitrovica during this researching period of time have applied this institute to only 557 criminal cases resolution. Hence, by bearing in mind the great importance that plea agreement has, it is necessary the same to be more promoted by Kosovo Judicial Council and civil society in general. Also, it is required in the future for Kosovo courts to apply more often this criminal case resolution institute. In this regard, it is necessary for Kosovo judges and prosecutors to be conducted respective training programs that would enable and motivate them toward more frequent application of this institute when it comes to resolution of criminal cases.

\section{References}

Bojović, V., 2009. Plea agreement. Beograd: Literature. pp: 56.

Damaška, M., 2004. Agreements in criminal procedure. Croatian Annual of Criminal Law and Practice, Zagreb, 1(1): 61.

Hajdari, A., 2010. Criminal procedure, commentary. Pristina: FAMA College. pp: 546. 
Hajdari, A., 2013. Criminal procedure law, special part. Prishtina: ILIRIA College. pp: 40.

Hajdari, A., 2016. Commentary, criminal procedure code. Prishtina: FAMA College. pp: 619.

Hajdari, A., 2016. The resolution of criminal case through temporary suspension of proceedings Kosovo context. International Journal of Development and Sustainability, 5(10): 508-517.

Hajdari, A., 2016. Conditional release of convicted persons in Kosovo. International Journal of Research in Humanities and Social Studies, $3(7): 32-39$.

Islami, H., A. Hoxha and I. Panda, 2003. Criminal procedure, commentary. Tirana: University of Tirana. pp: 450-451.

Latifi, V., I. Elezi and V. Hysi, 2012. Policy of combating criminality. Prishtina: University of Prishtina. pp: $257-259$.

Markus, F., 2006. Kosovo trial skills handbook. Pristina: GTZ Pristina. pp: $67-68$.

Milutinović, M., 1984. Criminal policy. Pristina: University of Prishtina. pp: $321-323$.

Nikolić, D., 2009. Party agreement. Beograd: University of Beograd. pp: 21.

Sahiti, E. and R. Murati, 2013. Criminal procedure law. Prishtina: University of Prishtina. pp: 330.

Sahiti, E., R. Murati and X. Elshani, 2014. Criminal procedure code of the Republic of Kosovo, commentary. Prishtina: GTZ Prishtina. pp: 595.

Thaman , S., 2002. Approval in comparative law. The Croatian Chronicle is a Scheduled Law and Practice, Zagreb, 9(1).

Citation | Albulena Hajdari (2018). The Role of Plea Agreement in Resolution of a Criminal Case in the Criminal Proceedings of the Republic of Kosovo. International Journal of Social Sciences and English Literature, 2: 1-6. English

History:

Received: 13 November 2017

Revised: 27 December 2017

Accepted: 4 January 2018

Published: 9 January 2018

Licensed: This work is licensed under a Creative Commons

Attribution 3.0 License (cc) E E

Publisher: Eastern Centre of Science and Education

Eastern Centre of Science and Education is not responsible or answerable for any loss, damage or liability, etc. caused in relation to/arising out of the use of the content. Any queries should be directed to the corresponding author of the article.
Funding: This study received no specific financial support

Competing Interests: The authors declare that they have no conflict of interests.

Transparency: The authors confirm that the manuscript is an honest, accurate, and transparent account of the study was reported; that no vital features of the study have been omitted; and that any discrepancies from the study as planned have been explained.

Ethical: This study follows all ethical practices during writing. 